\section{Investigation of Early Literacy Skills in Preschool Children With Deaf and Hard of Hearing*}

\author{
Pelin Piştav-Akmeşe ${ }^{a,{ }^{* *}}$, Destina Sezgin ${ }^{b}$, Fatih Öğüt ${ }^{c}$
}

$\begin{array}{ll}\text { Received: } & 5 \text { July } 2019 \\ \text { Revised: } \quad 28 \text { October } 2019 \\ \text { Accepted: } \quad 22 \text { November } 2019 \\ \text { ISSN: } 1307-9298 \\ \text { Copyright } \odot \text { IEJEE } \\ \text { www.iejee.com }\end{array}$

DOI: 10.26822/iejee.2019257659

\title{
Abstract
}

In this study, it is aimed to compare the early literacy skills of children with cochlear implants with 60-72 months of preschool and / or special education to the results of children with normal hearing. For this purpose, the following questions were sought. In this study, "Demographic Form" containing the general information of volunteer families and children was included in the study and Early Literacy Test-EROT was applied to evaluate the early literacy skills of children. As a result, word knowledge between two groups, receptive and expressive language, general naming, knowledge of function scores were statistically different; in the phonological awareness sub-tests, the difference between separating the word into syllable, combining syllables, eliminating the first sound of words results with cochlear implants were statistically significant between two groups. However, there was no statistically significant difference between groups in terms of rhyme awareness, matching the first sound of words, matching the last sound of words, separating the sentence into words, eliminating the last voice of words and total phonological awareness scores; moreover, it was found that $\mathrm{Cl}$ users had lower scores in the knowledge of letter, listening comprehension subtests and EROT total scores, and the difference between the groups was significant.

Keywords: Cochlear Implant, Hearing Loss, Deaf, Early Literacy, Preschool Children

\section{Introduction}

One of the goals of the education of hearing-impaired children is to develop language skills and verbal /auditory communication skills according to their chronological age. It is essential for children to have a sense of hearing in order to develop their receptive and expressive language skills and to adapt to social life (Gündüz \& Karabulut, 2015). With the development of these skills, children with hearing loss have access to educational opportunities with their normal hearing peers. As the level of hearing loss of the child increases, it is difficult to achieve these goals.

Children with deaf and hard of hearing are in the risk group in terms of serious language difficulties in early stages and literacy difficulties in the school period. In recent years, in paralle with the developments in new born hearing screening programs, hearing aids and cochlear implantation technology, positive predictions have begun to be made for children with deaf and hard of hearing. It has been reported that many of these children are detected by new born screening and that speech perception and language skills increase due to advances such as: Cochlear implant technology, early diagnosis and very early education (Geers, Nicholas, \& Sedey, 2003).

In recent years, cochlear implant $(\mathrm{Cl})$ has become a preferred method in the hearing technology of advanced and very severe hearing loss (Lachowska, Pastuszka, Łukaszewicz-Moszy, Mikołajewska \& Niemczyk, 2016; Utrup \& Schafer 2016). Developments in cochlear implant technology have increased the success rate of early rehabilitation of children with severe hearing loss and their opportunity to receive education with their peers. At this point, a comprehensive assessment of communication, language and speech skills of children using cochlear implants has become more important (Blamey et al., 2001).

The most important difficulties of the hearing problem, which can be reduced by early cochlear intervention are verbal lan- guage input and necessity of special education assistance. In this way, children with severe hearing loss can have similar language development with their peers. Tezer and Akar (2009), stated that the listening skills have increased with the special education received after the implantation. At the same time, the rate of children's understanding of spoken language is stated to be over $80 \%$.

Piștav-Akmeşe (2015) stated that children's communication type and type of school were related to language results as well as intensive auditory verbal education, and children who participated in inclusive education, had significantly higher scores in language areas. Although, children with hearing loss who attend mainstream schools are good in language areas, they have significant difficulties in the syntactic processes of certain morphological structures, the main elements of the story and the narration of the story; even though their participation in the mainstreaming program makes them good in general language areas, the emphasis is that they should be supported by special intervention programs focusing on specific language structures (Piştav-Akmeşe 2015; Piştav-Akmeşe \& Acarlar 2016). Considering the relationship between early language skills and advanced literacy skills; in these special education programs, such as early literacy program, as explained in detailed in below, it is important to support the basic skills of reading and writing in pre-school period. Because, in early childhood, children go through the fastest stage of their development, where not only their personality is built but also they are strongly affected by their immediate environments and open to any kind of learning (Öztürk \& Demir 2018). Hence, in this early childhood period certain basic skills mentioned above could be developed since children are open to any kind of learning.

The basic skills of pre-school literacy are considered as early literacy. Early literacy is defined as the skills and attitudes that started in infancy and are supported and developed during early childhood (Yazıcı \& Kandır, 2018). Early literacy begins with children's natural environments at home and in kin- 
dergarten, with children's reading and writing knowledge acquired before they are formally exposed to reading at school. It includes various skills such as early literacy, grammar, phonological awareness and orthographic (writing) awareness. These skills predict children's academic achievement in school (Kargın, Ergül, Büyüköztürk, \& Güldenoğlu, 2015). Most, et al., (2006) reported that skills of phonological awareness in kindergartens predicted future success in gaining reading and writing skills, Kargın, Ergül, Büyüköztürk and Güldenoğlu, (2015) stated that the first year of primary school aims to improve reading-writing skills, however studies in the literature stated that the children start school without necessary attitude and skills and have difficulty in learning reading and writing. The importance of pre-school literacy is emphasized in order for children to acquire the skills they need for school (Snow, 2008). Moreover, it is stated that there is a strong relationship between early literacy skills and reading and academic achievement of children, and that children with good literacy skills in preschool period are successful in both academic and social fields (Kargın, Ergül, \& Güldenoğlu, 2018).

However, there are limited number of studies on early reading basic skills for young children with deaf and hard hearing in Turkey according to Atlar and Uzuner. It is determined by Atlar and Uzuner (2018) that a child with hearing loss needs to be considered in the context of developing literacy experiences in preschool period. Recent studies have shown that young children with deaf and hard of hearing and with proper language, develop phonological awareness but are less likely to develop than those with normal hearing. Easterbrooks, Lederberg, Miller, Bergeron and Connor (2008) investigated the phonological awareness skills of children aged 5-10 years with cochlear implants and hearing aids; for children with cochlear implants, hearing test results which are compatible with hearing loss have been obtained. It was stated that children with cochlear implant surgery after preschool period showed more syllable, phonemic and alert awareness than the children who had implanted at an older age. Easterbrooks, Lederberg, Miller, Bergeron and Connor emphasized that rhyme awareness skills of children with cochlear implants predicted word recognition scores in preschool period (5-7 years). Geers, Nicholas and Sedey has reported that low literacy is frequently seen in students with severe hearing loss and this is partly due to the contradiction between expressive language and the learning based on a speech-based system (Geers, Nicholas, \& Sedey, 2003). In Mayer's study of early literacy development, 2 children with severe hearing loss were found to have similar results to their hearing peers, however, 50\% of hearing loss students graduated from secondary school with a level of reading of fourth grade or even lower, hence, $30 \%$ is underlined to leave the school with out being able to learn functional reading and writing. At this point, it was stated that there was a close connection between language acquisition and subsequent literacy development and it would be relatively easier for children who start school to have a better level of language skills than the transition to text-based literacy (Mayer, 2007). Early literacy is defined as the knowledge and skills acquired by children before learning reading and writing (Kargın et al., 2015). It is important to evaluate the language skills of preschool children who are normally developing and do not have hearing problem and who has hearing problem and at risk for language development before starting primary school. Assessing the readiness of preschool children with hearing problem to school in terms of language development and the positive role of cochlear implantation in this process will support their academic achievement.

Therefore, in this study, it is aimed to compare the early literacy skills of children with cochlear implants with 60-72 months of preschool students and / or attending special education (support for certain designated hours of the week for language and literacy development) to the results of children with normal hearing. For this purpose, the following questions were sought.

1. Does the EROT (Test of Early Literacy -TEL) vocabulary sub-test scores of children in the $\mathrm{Cl}$ (cochlear implant) and ND (normal development) group differ?
2. Do EROT phonological awareness sub-test scores of children in $\mathrm{Cl}$ and ND group differentiate?

3. Do the EROT letter knowledge sub-test scores of children in the $\mathrm{Cl}$ and ND group differ?

4. Is there any difference in the EROT listening comprehension sub-test of children in the $\mathrm{Cl}$ and ND group?

5. Do the EROT total test scores of children in the $\mathrm{Cl}$ and ND group differ?

6. Is there a relationship between sex, maternal education level and age of diagnosis of hearing loss and EROT subtests?

\section{Method}

The aim of the study was to investigate the early literacy skills of preschool children who had undergone cochlear implant surgery before 4 years of age and to compare them with children with normal hearing; and to search the effects of early implant on language development.

The research was conducted between July 2018 - December 2018. After the approval of the ethics committee, volunteer children aged 5-6 years (60-72 months) who applied to Ege University Medical Faculty Otorhinolaryngology Department were included in the study. For the study group: Children aged 5-6 years who had undergone cochlear implant surgery at Ege University School of Medicine, Department of Otorhinolaryngology; For the control group: Ege University Faculty of Medicine Department of Otorhinolaryngology, no ear pathology was detected as a result of the tests, children with normal hearing 5-6 years old were included.

In this study which was planned according to descriptive survey method, "Demographic Form" containing the general information of volunteer families and children were included in the study and Early Literacy Test-EROT was applied to evaluate the early literacy skills of children.

\section{Data Collection Tools}

\section{Demographic form}

The demographic form is formed by the researchers, including questions about the children's families and children's demographic information. Information was obtained by means of individual interviews with the families who volunteered to participate in the study.

\section{Test of early literacy (TEL/ EROT)}

Turkish validity and reliability of the test was performed by Kargın, Ergül and Güldenoğlu and EROT (Test of Early Literacy, TEL). EROT test consists of three main booklets. These are vocabulary; phonological awareness; the knowledge of alphabet and listening comprehension booklet. The first part consists of four subtests. Sub-tests of this section are; receptive and expressive language, general naming and knowledge of function. The receptive-expressive language sub-test consists of 1 sample item and 15 questions. General naming and function information consists of 1 sample item and 10 questions. The second part is composed of four sub-tests in a similar way as phonological awareness; rhyme awareness, matching according to the first voice, matching according to the last voice, dividing the sentence into words. The subtests in this section consist of 2 samples and 4 question items. The third chapter is the alphabet knowledge and listening comprehension booklet. In this part letters in receptive and expressive language is asked. In the listening comprehension section, a short story is told and 6 questions are asked to the participant. The researcher asks the children questions according to the instructions in the test battery (Kargın, Ergül, Büyüköztürk, \& Güldenoğlu, 2015). The EROT test, consisting of seven different subtests, was per- 
formed in a quiet room in the study. The evaluation period lasted approximately 30 minutes. When children were bored during the test or were distracted, 10 minutes of breaks were given and the test was administered as two sessions.

\section{Data Analysis}

Research data were analysed with SPSS 25.0 package program. The data were analysed by the Shapiro Wilk analysis to see if it conforms to normal distribution. $\mathrm{Cl}$ and ND children were analysed by Mann Whitney $U$ test to see whether the data differs from school readiness test EROT. Spearman correlation test was done in order to find whether there was a relation between EROT and the study's independent variables.

\section{Results}

The study included $20 \mathrm{Cl}$ children aged between 5 and 6 years and 20 ND children matched by age and gender. Table 1 provides information on the demographic characteristics of children.

In Table 1, a total of 40 children were evaluated. 20 of the children are boys and 20 of them are girls. There are 10 boys and 10 girls in both groups. It was observed that 4 of the children in the $\mathrm{Cl}$ group solely continued their special education and 16 of them continued to both special education centre and kindergarten. All children in the ND group go to kindergarten. Fourteen (70\%) of the children were diagnosed with new born hearing screening, 5 (25\%) were diagnosed between 6-12 months and $1(5 \%)$ were diagnosed over 2 years of age. Of the children, $9(45 \%)$ had undergone $\mathrm{Cl}$ surgery in 18 months, 6 (30\%) had between 19-24 months, and 5 (25\%) had undergone surgery after 2 years of age. The mean age of the participants in the study group was $66.70 \pm 5.31$ months (min: 57 months, max: 72 months). Mean age of children with ND who were matched for \pm 3 months was $65.45 \pm 4.24$ months (min: 59 months, max: 71 months). The mean age of the $\mathrm{Cl}$ children were $33.85 \pm 4.24$ years ( $\min : 26$, $\max : 43$ ) and the mean age of the children with ND was $33.20 \pm 4.79$ (min: 23, max: 39) years. When mothers are examined according to their education levels; 9 (45\%) of the mothers of $\mathrm{Cl}$ children with primary and secondary school, 7 (35\%) high school and $4(20 \%)$ university graduates. 3 of the mothers of ND children (15\%) were elementary and middle school, 6 (30\%) were high school and $11(55 \%)$ were university graduates. In terms of occupations, 17 (85\%) mothers of $\mathrm{Cl}$ children are housewives and $3(15 \%)$ work. Moreover, $10(50 \%)$ mothers of ND children are housewives and 10 (50\%) mothers work.

Table 2 shows the EROT vocabulary scores of the children in the $\mathrm{Cl}$ and ND group, which is the first sub-objective of the study.

When table 2 is examined, the vocabulary of the two groups in the receptive language $(U=98.50, p<.05)$, the vocabulary in the expressive language $(U=104, p<.05)$, the general naming $(U=118, p<.05)$, knowledge of function $(U=105, p<.05)$ and total vocabulary $(U=92, p<.05)$ sub-tests showed that there was a significant difference between the $\mathrm{Cl}$ and ND groups.

For the second sub-objective of the study, the results of the analysis for the question "Do EROT phonological awareness sub-test scores of children in $\mathrm{Cl}$ and ND group differentiate?" are given in Table 3.

Table 1. Demographic Characteristics of Cl and ND Children

\begin{tabular}{lccrr}
\hline Variables & $\mathrm{Cl}$ & & $\mathrm{ND}$ \\
\hline Boy & $n$ & $\%$ & $n$ & $\%$ \\
\hline Girl & 10 & 50.0 & 10 & 50.0 \\
\hline Type of School & 10 & 50.0 & 10 & 50.0 \\
\hline Special Education & & & & \\
\hline Kindergarten and Special Education & 4 & 20.0 & - & - \\
\hline Kindergarten & 16 & 80.0 & - & - \\
\hline Age of Diagnosis & - & - & 20 & 100 \\
\hline New Born Hearing Screen & & & & \\
\hline 6-12months & 14 & 70.0 & - & - \\
\hline 2 years and older & 5 & 25.0 & - & - \\
\hline Age of Cl Surgery & 1 & 5.0 & - & - \\
\hline 18 months before & & & & - \\
\hline Between 19-24 months & 9 & 45.0 & - & - \\
\hline 25 month and older & 6 & 30.0 & - & - \\
\hline
\end{tabular}

Table 2. Mann Whitney U Test Results in EROT Vocabulary Sub-Tests of CI Group and ND Group

\begin{tabular}{|c|c|c|c|c|c|c|}
\hline & Group & $n$ & Mean Rank & Sum of Ranks & $u$ & $p$ \\
\hline \multirow{2}{*}{ EROT Receptive Vocabulary Knowledge } & $\mathrm{Cl}$ & 20 & 15.43 & 309 & \multirow{2}{*}{998.50} & \multirow{2}{*}{$.006^{*}$} \\
\hline & ND & 20 & 25.58 & 512 & & \\
\hline \multirow{2}{*}{ EROT Expressive Vocabulary Knowledge } & $\mathrm{Cl}$ & 20 & 15.70 & 350 & \multirow{2}{*}{1104} & \multirow{2}{*}{$.009^{*}$} \\
\hline & ND & 20 & 25.30 & 470 & & \\
\hline \multirow{2}{*}{ EROT General Naming } & $\mathrm{Cl}$ & 20 & 16.40 & 328 & \multirow{2}{*}{1118} & \multirow{2}{*}{$.024^{*}$} \\
\hline & ND & 20 & 24.60 & 492 & & \\
\hline \multirow{2}{*}{ EROT Knowledge Function } & $\mathrm{Cl}$ & 20 & 15.75 & 315 & \multirow{2}{*}{1105} & \multirow{2}{*}{$.009^{*}$} \\
\hline & ND & 20 & 25.25 & 450 & & \\
\hline \multirow{2}{*}{$\begin{array}{l}\text { EROT Total } \\
\text { Vocabulary Knowledge }\end{array}$} & $\mathrm{Cl}$ & 20 & 15.10 & 302 & \multirow{2}{*}{992} & \multirow{2}{*}{$.003^{*}$} \\
\hline & ND & 20 & 25.90 & 518 & & \\
\hline
\end{tabular}


Table 3. The Mann Whitney U Test Results in EROT Phonological Awareness Sub-Tests of the Cl and ND Group

\begin{tabular}{|c|c|c|c|c|c|c|}
\hline & Group & $n$ & Mean Rank & Sum of Ranks & $U$ & $p$ \\
\hline \multirow{2}{*}{ EROT Rhyme Awareness } & $\mathrm{Cl}$ & 20 & 18.28 & 366 & \multirow{2}{*}{156} & \multirow{2}{*}{.217} \\
\hline & ND & 20 & 22.73 & 455 & & \\
\hline \multirow{2}{*}{ EROT Matching First Sound of Words } & $\mathrm{Cl}$ & 20 & 20.85 & 417 & \multirow{2}{*}{193} & \multirow{2}{*}{.815} \\
\hline & ND & 20 & 20.15 & 403 & & \\
\hline \multirow{2}{*}{ EROT Matching Last Sound of Words } & $\mathrm{Cl}$ & 20 & 20.88 & 417 & \multirow{2}{*}{193} & \multirow{2}{*}{.789} \\
\hline & ND & 20 & 20.13 & 403 & & \\
\hline \multirow{2}{*}{ EROT Separating the Sentence into Words } & $\mathrm{Cl}$ & 20 & 19.00 & 380 & \multirow{2}{*}{170} & \multirow{2}{*}{.384} \\
\hline & ND & 20 & 22.00 & 440 & & \\
\hline \multirow{2}{*}{ EROT Separating the Word into Syllable } & $\mathrm{Cl}$ & 20 & 16.10 & 322 & \multirow{2}{*}{112} & \multirow{2}{*}{$.008^{*}$} \\
\hline & ND & 20 & 24.90 & 498 & & \\
\hline \multirow{2}{*}{ EROT Combining Syllables } & $\mathrm{Cl}$ & 20 & 15.68 & 314 & \multirow{2}{*}{103} & \multirow{2}{*}{$.004^{*}$} \\
\hline & ND & 20 & 25.33 & 207 & & \\
\hline \multirow{2}{*}{ EROT Eliminating First Sound of Words } & $\mathrm{Cl}$ & 20 & 22.50 & 450 & \multirow{2}{*}{160} & \multirow{2}{*}{$.038^{*}$} \\
\hline & ND & 20 & 18.50 & 370 & & \\
\hline \multirow{2}{*}{ EROT Eliminating Last Voice of Words } & $\mathrm{Cl}$ & 20 & 21.00 & 420 & \multirow{2}{*}{190} & \multirow{2}{*}{.317} \\
\hline & ND & 20 & 20.00 & 400 & & \\
\hline \multirow{2}{*}{ EROT Phonological Awareness } & $\mathrm{Cl}$ & 20 & 17.38 & 348 & \multirow{2}{*}{138} & \multirow{2}{*}{.090} \\
\hline & ND & 20 & 23.63 & 473 & & \\
\hline
\end{tabular}
${ }^{*} p<.05$

Table 4. Mann Whitney $U$ Test Results of EROT Alphabet Sub-Tests of the Cl and ND Group

\begin{tabular}{|c|c|c|c|c|c|c|}
\hline & Group & $n$ & Mean Rank & Sum of Ranks & $u$ & $p$ \\
\hline \multirow{2}{*}{ EROT Receptive Letter Knowledge } & $\mathrm{Cl}$ & 20 & 15.88 & 317 & \multirow{2}{*}{108} & \multirow{2}{*}{$.007^{*}$} \\
\hline & ND & 20 & 25.13 & 5502 & & \\
\hline \multirow{2}{*}{ EROT Expressive Letter Knowledge } & $\mathrm{Cl}$ & 20 & 16.78 & 335 & \multirow{2}{*}{126} & \multirow{2}{*}{$.022^{*}$} \\
\hline & ND & 20 & 24.23 & 4484 & & \\
\hline \multirow{2}{*}{ EROT Total Score of the Letter Knowledge } & $\mathrm{Cl}$ & 20 & 15.88 & 317 & \multirow{2}{*}{108} & \multirow{2}{*}{$.007^{*}$} \\
\hline & ND & 20 & 25.13 & 5502 & & \\
\hline
\end{tabular}

Table 5. The Mann Whitney U-Test Results of EROT- Listening Comprehension Test of the Cl and ND Group

\begin{tabular}{llllrlll}
\hline & Group & $n$ & Mean Rank & Sum of Ranks & $U$ & $p$ \\
\hline \multirow{2}{*}{ EROT Listening Comprehension } & $\mathrm{Cl}$ & 20 & 17.05 & 341 & & 131 & .054 \\
\cline { 2 - 6 } & $\mathrm{ND}$ & 20 & 23.95 & 479 & & \\
\hline
\end{tabular}

When Table 3 is examined, rhyme awareness $(U=156, p>.05)$ matching the first sound of words $(U=193, p>.05)$, matching the last sound of words $(U=193, p>.05)$, separating the sentence into words $(U=170, p>.05)$, eliminating the last voice of words $(U=190, p>.05)$ and total phonological awareness $(U=$ $138, p>.05)$ shows no significant difference between $\mathrm{Cl}$ and ND group; hence, separating the word into syllable $(U=112, p<$ $.05)$, combining syllables $(U=103, p<.05)$ and eliminating the first sound of words $(U=160, p<.05)$ shows a significant difference between the two groups.

For the third sub-objective of the study, the results of the Mann Whitney U Test for the question "Do the EROT letter knowledge sub-test scores of children in the $\mathrm{Cl}$ and ND group differ?" are presented in Table 4.

Table 4 , in the receptive letter knowledge $(U=108, p<.05)$, in the expressive letter knowledge $(U=126, p<.05)$ and the total score of the letter knowledge $(U=108, p<.05)$ shows a significant difference between $\mathrm{Cl}$ and ND groups.

For the fourth sub-objective of the study, the results of the Mann-Whitney U Test for the question "Do the children in the $\mathrm{Cl}$ and ND groups differ according to the EROT?" are presented in Table 5.
In Table 5, the mean of the $\mathrm{Cl}$ group in the listening test was 17.05 and the ND group has an average of 23.95. There was no significant difference between the group with $\mathrm{Cl}$ and the group with ND $(U=131, p>.05)$.

For the fifth sub-objective of the study, the results of the test for the question "Is there any difference in the EROT listening comprehension sub-test of children in the $\mathrm{Cl}$ and ND group?" are given in Table 6.

When Table 6 is examined, it is seen that the average of the $\mathrm{Cl}$ group in EROT is 16.10, while the average of ND group is 24.90 and there is a significant difference between the group with $\mathrm{Cl}$ and ND group $(U=190, p<.05)$.

When the test results of the EROT test's subscales and overall total scores are evaluated in detail: In the vocabulary sub-test of the recipient language, $70 \%$ of the children with $\mathrm{Cl}$ needs support and $30 \%$ of the children are in the normal limits of early literacy skills. In the ND group, the number of children in need of support was $40 \%$ and $60 \%$ were within normal limits. $85 \%$ of the children in $\mathrm{Cl}$ group in the vocabulary expressive sub-test were in need of support and $\% 15$ were in normal limits. In the control group, support was required for $60 \%$ children 
Table 6. Mann Whitney U-Test Results in EROT Total Scores of Cl and ND Group

\begin{tabular}{llllrll}
\hline & Group & $n$ & Mean Rank & Sum of Ranks & $U$ & $p$ \\
\hline \multirow{2}{*}{ EROT Total Score } & $\mathrm{Cl}$ & 20 & 16.10 & 322 & \multirow{2}{*}{112} & $.017^{\star}$ \\
\cline { 2 - 6 } & $\mathrm{ND}$ & 20 & 24.90 & 498 & & \\
\hline$x_{p<.05}$
\end{tabular}

Table 7. Correlation between Gender, Maternal Education Level, Age of Diagnosis of Hearing Loss and EROT Subtest

\begin{tabular}{|c|c|c|c|c|c|c|c|}
\hline & Group & $r-p$ & $\begin{array}{r}\text { EROT Receptive } \\
\text { Vocabulary Knowledge }\end{array}$ & $\begin{array}{l}\text { EROT Phonol. } \\
\text { Awareness }\end{array}$ & $\begin{array}{r}\text { EROT Knowledge } \\
\text { Letter }\end{array}$ & $\begin{array}{l}\text { EROT List. } \\
\text { Comp. }\end{array}$ & EROT Total \\
\hline \multirow{6}{*}{$\mathrm{Cl}$} & \multirow{2}{*}{ Gender } & $r$ & .087 & .289 & $.000^{*}$ & .231 & .165 \\
\hline & & $p$ & .716 & .217 & 1.00 & .327 & .487 \\
\hline & \multirow{2}{*}{ Mother Education } & $r$ & .541 & .378 & .187 & .518 & .471 \\
\hline & & $p$ & $.014^{*}$ & .100 & .430 & $.019^{*}$ & $.036^{*}$ \\
\hline & \multirow{2}{*}{ Age of Hearing Loss } & $r$ & .099 & .378 & .322 & -.121 & .197 \\
\hline & & $p$ & .678 & 160 & 166 & .611 & .405 \\
\hline \multirow{4}{*}{ ND } & \multirow{2}{*}{ Gender } & $r$ & .166 & .201 & -.097 & -.201 & $-.017^{*}$ \\
\hline & & $p$ & .484 & .395 & .685 & .934 & .942 \\
\hline & \multirow{2}{*}{ Mother Education } & $r$ & .536 & .176 & .106 & -.158 & .402 \\
\hline & & $p$ & $.015^{*}$ & .459 & .656 & .505 & .079 \\
\hline
\end{tabular}

$* p<.05$

and $40 \%$ did not need support. In the general naming subtest, $65 \%$ children in the $\mathrm{Cl}$ group needed support while $35 \%$ were in the normal range. In the control group, $45 \%$ children needed support in the general naming area and 55\% children were within normal limits. In the function of knowledge sub-test, $60 \%$ in $\mathrm{Cl}$ group were below the cut-off point and $40 \%$ were in the normal range. In the ND group, $15 \%$ children were in need of support and $85 \%$ did not need support in this part of the test. In the phonological awareness subscales, it was seen that $75 \%$ children needed support in the group with $\mathrm{Cl}$ and $25 \%$ were within the normal limits, while in the ND group, 18 (90\%) children's phonological awareness skills needed support, $10 \%$ of the children were within normal limits. In alphabet knowledge, $80 \%$ of the children in the $\mathrm{Cl}$ group had the need for support and $20 \%$ were within the normal limits, while in the ND group, $45 \%$ of the children's alphabet knowledge skills needed support and \% 55 of the children were in the normal range. In the listening comprehension subtest, $75 \%$ of the children in the $\mathrm{Cl}$ group needed support and 25\% were in the normal range and in the ND group, $80 \%$ children needed support and $20 \%$ children were within normal limits. In the EROT total score, 75\% children in the study group and 55\% children in the control group were below the cut-off point and needed to support early literacy skills.

For the sixth sub-objective of the study, the results of the Spearman correlation analysis for the question "Is there a relationship between gender, maternal education level and age of diagnosis of hearing loss and EROT subtests?" are given in Table 7.

There is no statistically significant relationship between gender and age of diagnosis of the hearing loss with EROT subtests. There is a statistically significant relationship between EROT vocabulary, listening comprehension and EROT total scores and maternal education $(p<.05)$. In the NG group, there was no significant relationship between gender with EROT subtests $(p>.05)$, and there was a significant relationship between EROT vocabulary sub-test $(p<.05)$.

\section{Discussion}

In this study, we aimed to compare the early literacy skills of children with cochlear implants $(\mathrm{Cl})$ with $60-72$ months of preschool and / or special education with the results of chil- dren with normal hearing. Whether there was a difference between the $\mathrm{Cl}$ and ND children and their scores on the EROT scale were analysed on the frame of subtests of EROT. Differences between study and control groups were examined according to sub-tests; vocabulary knowledge (receptive and expressive language, general naming, knowledge of function), phonological awareness (rhyme awareness, matching the first sound of words, matching the last sound of words, separating the sentence into words, separating the word into syllable, combining syllables, eliminating the first sound of words, eliminating the last voice of words, ) alphabet knowledge (receptive and expressive alphabet knowledge) and listening comprehension. When ND children were compared with $\mathrm{Cl}$ users according to the vocabulary knowledge subtest scores; study group was found below and there were significant differences between the groups. In the study group, 60\% of them needed support in the field of receptive language, $\% 85$ in expressive language, \%65 in general naming, \%60 in knowledge of function, $75 \%$ in phonological awareness, $80 \%$ in the alphabet knowledge, 75\% in listening comprehension and $75 \%$ needed support for all EROT skills. Supporting the results of this study, Nicholas and Geers (2007) emphasized that children with severe hearing loss had lower vocabulary than expected. Kyle and Harris (2010) emphasizes the importance of language skills for the reading of hearing-impaired children.

In this study, study group needed support in all areas of vocabulary knowledge. In control group, $40 \%$ of them needed support in receptive language, 60\% in expressive language, $45 \%$ in general naming, $15 \%$ needed support in the knowledge of function. Studies in the literature show a strong relationship between early literacy skills and reading and academic achievement of children (Rohde, 2015). It has been underlined that children who have good early literacy skills in pre-school period are successful in both academic and social fields, and children with underdeveloped skills experience great difficulties in learning process (Kargın, Ergül, Büyüköztürk, \& Güldenoğlu, 2015). Another study shows that there is a clear link between verbal and written language, and this link is the vocabulary knowledge. In order for a reader to understand the text, it is stated that most of the words represented by the text should be in the verbal expression of the reader, in other words, the fact that children can understand the sentence spoken in the preschool period predicts understanding in the future (Kyle \& Harris 2006). 
In our study, it was found that in the phonological awareness sub-tests, the difference between separating the word into syl lable, combining syllables, eliminating the first sound of words results with cochlear implants were statistically significant between two groups. However, there was no statistically significant difference between groups in terms of rhyme awareness, matching the first sound of words, matching the last sound of words, separating the sentence into words, eliminating the last voice of words and total phonological awareness scores. In the detailed analysis, taking into account the cut points of the test, $90 \%$ of the children in ND needed support and $75 \%$ of the children in $\mathrm{Cl}$ needed support. When the studies conducted in the literature are examined, it can be seen in the study of Kyle and Harris that even though hearing impaired individuals can be aware of the rhymes of words, even university students in their academic lives (rhyme awareness), they are generally more wrong and slower in reading than normal individuals (Kyle \& Harris, 2006). In another study, James, Helbig, Maier, Kiefer Radeloff and Adunka (2008) reported that children with hearing impaired were significantly lower than their peers in rhyme awareness. It is thought that the difference between the literature and the results can be caused by the fact that children in the study group with $\mathrm{Cl}$ have received training for phonological awareness in special education programs, but children who have normal development in kindergarten in Turkey have very limited awareness of phonological awareness in education program. In addition, in the August-December period when data collection was made, there were no training done in the kindergarten education curriculum, except for separating the word into syllable and combining syllables. As a result, it can be foreseen that different results can be obtained in the other studies with the data collection for example in May or June. Therefore, it is thought that the difference between the $\mathrm{Cl}$ and ND in the phonological awareness area may be derived from the data collection period compared to the literature.

In the knowledge of alphabet, when compared between two groups, the $\mathrm{Cl}$ children showed lower performance than the normal hearing group. Although the difference between groups was significant in the sub-tests of knowledge of alphabet, sub-test scores of the alphabet were found to be low in both of the groups. $80 \%$ of the children in the study group and $45 \%$ of the control group needed support in the letters. It is thought that children in both groups will get higher scores if knowledge of alphabet takes more places in education programs. Easterbrooks et al., states in his study that children with severe hearing loss between 9 and 14 years of age showed high performance in matching letters, supporting the importance of education in letter knowledge (Easterbrooks, Lederberg, Miller, Bergeron, \& Connor, 2008).

Another sub-skill that the EROT test considers is listening comprehension. When the groups were compared according to the comprehension scores of the EROT test, there was a significant difference between the two groups. When the results are examined in detail, the mean score of the ND group is higher. However, when the cut points of the test were taken into consideration, $80 \%$ children from ND group and $75 \%$ children from $\mathrm{Cl}$ group need to be supported in listening comprehension. Supports the results of this study Geers (2002), stated in her research that, $\mathrm{Cl}$ children starting primary school, performed below grade level in the areas of vocabulary knowledge and listening comprehension. In this sense, the importance of gaining listening comprehension skills before starting schoo is made obvious. In a study in which $\mathrm{Cl}$ children were followed for 3 years, the process of reading mother and child interactive books was evaluated. It was stated that they received lower scores in the evaluation tests before the group interactive book reading education and they showed above average performance after the interactive book reading education. Moreover, Desjardin's study, is an important study showing that vocabulary knowledge, listening comprehension and phonological awareness skills can be developed with appropriate support and rehabilitation (Desjardin, Ambrose, \& Eisenberg, 2008).
When the groups were compared according to the EROT total scores obtained by the sum of all subtests of the EROT test, a significant difference was found between the two groups. When the results are analysed in detail according to cut points; $75 \%$ children in the study group and 55\% children with control group need to be supported. When the reading and writing skills are nurtured from the spoken language, the skills developed in the oral language, i.e. both the receptive and the expressive language are very important for reading and writing. In the literature, it is emphasized that there are strong predictive relationships between language skills including vocabulary and reading ability (Kyle \& Harris, 2006). It is emphasized that $50 \%$ of hearing impaired students graduated from secondary school with a fourth grade reading level (Traxler, 2000) and $30 \%$ were low in literacy at school and could not even perform functional reading and writing according to age (Lang, 2002). In this study, when the relationship between EROT subtests with gender, maternal education level and age of diagnosis is examined; It was found that there was a significant relationship between mother education levels and EROT subtests and these factors influenced children's language skills. Moreover, Altan, and Uzuner (2018) have underlined the important literal impact of the adult who spends a lot of time with the children. Supporting the results of our study, Desjardin et. reported that there was a positive correlation between speech and language development of children and maternal education and participation (Desjardin \& Eisenberg, 2007). In our study, according to the history of the mothers with the study group it is related that there is a relationship between mothers education level and EROT subtests, since the mothers have stated there were the adult spending a lot of time with their children.

\section{Conclusions}

As a result, in this study, word knowledge between two groups, receptive and expressive language, general naming, knowledge of function scores were statistically different; in the phonological awareness sub-tests, the difference between separating the word into syllable, combining syllables, eliminating the first sound of words results with cochlear implants were statistically significant between two groups. However, there was no statistically significant difference between groups in terms of rhyme awareness, matching the first sound of words, matching the last sound of words, separating the sentence into words, eliminating the last voice of words and total phonological awareness scores; moreover, it was found that $\mathrm{Cl}$ users had lower scores in the knowledge of letter, listening comprehension subtests and EROT total scores, and the difference between the groups was significant. When the children with $\mathrm{Cl}$ were compared the EROT total score showed lower performance than the ND group and the EROT test was evaluated according to the cut-off points and as a result, in the study group 15 (\%75) of the children and in control group 11 (\%55) of the children needed to be supported in early literacy skills. Even though participants in the study group were early detected in their hearing losses and had the surgery, the results of this study reveal the necessity of supporting the early literacy skills in their education programs, which are prerequisite skills for reading and writing skills, in terms of children who receive both mainstreaming education and special education in the risk group and/or who continue their education in kindergarten.

\section{Suggestions}

Based on the findings of the research, the suggestions developed for advanced research and applications are as follows.

- In order to increase the generalizability of the findings obtained from the study, the same study can be repeated by comparing with a larger research group.

- A similar study can be performed with children using hearing aids. 
- Different groups using hearing aid, bilateral implant and unilateral implant can be compared in terms of early literacy.

- Early literacy skills can be repeated in the same group with data collection in May, which is the period of graduating from kindergarten in Turkey.

- Parents or teachers of preschool students can incorporate early literacy skills into everyday life, to support children's future academic skills.

- Lesson plans in special education programs can be arranged according to early literacy skills to support early literacy skills of preschool children with hearing loss.

\section{References}

Atlar, H., Uzuner, Y. (2018). Examining the Emergent Literacy Experiences of a Preschool Child with Hearing Loss. Journal of Qualitative Research in Education - JOQRE, $57,54-89$.

Blamey, P.J., Sarant, J.Z., Paatsch, L.E., Barry J.G., Bow C.P., Wales R.J., Wright, M., Psarros C., Rattigan K. \& Tooher R. (2001). Relationships among speech perception, production, language, hearing loss, and age in children with impaired hearing. Journal of Speech Language and Hearing Research, 44(2), 264-285.

DesJardin, J.L. \& Eisenberg, L.S. (2007). Maternal contributions: Supporting language development in young children with cochlear implants. Ear and Hearing, 8(4), 456-469.

Desjardin, J.L., Ambrose, S.E. \& Eisenberg, L.S. (2008). Literacy skills in children with cochlear implants: the importance of early oral language and joint storybook reading. Journal of Deaf Studies and Deaf Education, 14(1), 22-43.

Easterbrooks, S.R., Lederberg, A.R., Miller, E.M., Bergeron, J.P. \& Connor C.M. (2008). Emergent literacy skills during early childhood in children with hearing loss: strengths and weaknesses. Volta Review, 108(2), 91114.

Geers, A.E. (2002). Factors affecting the development of speech, language, and literacy in children with early cochlear implantation. Language Speech and Hearing Services in Schools, 33(3), 172-183.

Geers, A.E., Nicholas, J.G. \& Sedey A.L. (2003). Language skills of children with early cochlear implantation. Ear and Hearing, 24, 46-58.

Gündüz, M., \& Karabulut, H. (2015). Odyolojide Temel Kavramlar ve Yaklaşımlar. Ankara, Nobel Kitap Evleri.

James, C.J., Helbig, S., Maier, N., Kiefer, J., Radeloff, A. \& Adunka, O.F. (2006). Ipsilateral electric acoustic stimulation of the auditory system: Results of long-term hearing preservation. Audiol-Neurotol, 11, 57-62.

Kargın, T., Ergül, C., Büyüköztürk, Ş. \& Güldenoğlu, B. (2015). Anasınıfı çocuklarına yönelik Erken Okuryazarlık Testi (EROT). Ankara Üniversitesi Eğitim Bilimleri Fakültesi Özel Eğitim Dergisi, 3(16), 237-268.

Kargın, T., Ergül, C. \& Güldenoğlu, İ. (2018). Erken okur yazarlık el kitap̧̧ı̆̆ı. Ankara: Eğiten Kitap.
Kyle, F.E., \& Harris, M. (2006). Concurrent correlates and predictors of reading and spelling achievement in deaf and hearing school children. Journal of Deaf Studies and Deaf Education, 11(3), 273-288.

Kyle, F.E., \& Harris, M. (2010). Predictors of reading development in deaf children: A 3 year longitudinal study. Journal of Experimental Child Psychology 107(3), 229243.

Lachowska, M., Pastuszka, A., Łukaszewicz Moszynska, Z., Mikołajewska, L., \& Niemczyk, K. (2016). Cochlear implantation in autistic children with profound sensorineural hearing loss. Brazilian Journal of Otorhinolaryngology, 84(1), 476-481.

Lang, H.G. (2002). Higher education for deaf students: research priorities in the new millennium. The Journal of Deaf Studies and Deaf Education, 7(4), 267-280.

Mayer, C. (2007). What really matters in the early literacy development of deaf children. Journal of Deaf Studies and Deaf Education, 12(4), 411-431.

Most, T., Aram, D., \& Andorn T. (2006). Early literacy in children with hearing loss: a comparison between two educational systems. Volta Review, 106(1), 5-28.

Nicholas, J.G., \& Geers, A.E. (2007). Will they catch up? The role of age at cochlear implantation in the spoken language development of children with severe to profound hearing loss. Journal of Speech Language and Hearing Research, 50(4), 1048.

Öztürk, Y.A. \& Demir, M.K. (2018). An Analysis of Graduate Theses on Early Childhood Education: The Case of Turkey. International Electronic Journal of Elementary Education, 10(5), 583-590.

Piştav Akmeşe, P. (2015). Doğuştan ileri/ çok ileri derecede işitme kayıplı çocukların dil becerilerine ilişkin çalışmların incelenmesi. Ege Eğitim Dergisi, 2(2), 392407.

Piştav Akmese, P., \& Acarlar, F. (2016). Using narrative to investigate language skills of children who are deaf and with hard of hearing. Educational Research and Reviews, 11(15), 1367-1381.

Rohde, L. (2015). The comprehensive emergent literacy model: early literacy in context. SAGE Open, 5(1), 1-11.

Snow, C.E. (2008). What counts as literacy in early childhood? K McCartney \& D Philips (Eds.). Handbook of Early Childhood Development (pp.274-294) Oxford, Blackwell Publishing.

Tezer, N., \& Akar, F. (2009). Geç yaşta koklear implant uygulamasinin geç dönem sonuçları. Çukurova Üniveristesi Eğitim Fakültesi Dergisi, 3(36), 81-91.

Traxler, C.B. (2000). Measuring up to performance standards in reading and mathematics: achievement of selected deaf and hard of hearing students in the national norming of the 9th edition Stanford achievement test. Journal of Deaf Studies and Deaf Education, 5, 337-348.

Yazıcı, E. \& Kandır, A. (2018). Erken okuryazarlık becerilerinin ev ortamında desteklenmesine iliş̧in çalışmaların incelenmesi. GEFAD, 38(1), 101-135. 